\title{
グローバル化に対応する社会運動における 国家と市民社会
}

東アジアからの視角

\section{大畑 裕 嗣*}

本稿の目的は，グローバル化に対応する社会運動に関する3つの異なった 分析枠組（反システム運動論，ネットワーク社会論，東アジア市民社会論） における国家／市民社会関係の位置づけを比較検討することを通じて，わた したちが生きている東アジアという地域の現実により根ざしつつ，グローバ ル化の時代に即応した，市民社会論の組み換えへの道を模索することにある.

反システム運動論は，国家と市民社会が明確に区分され，対抗しあうこと もあるという古典的な前提を踏襲しているが，おそらく反グローバル化運動 の実態と関連した戦略的計算のため，その点をあまり強調しなくなっている。 ネットワーク社会論は，ネットワーク社会における市民社会と国家の位相を 相対的に重視せず，国家／市民社会関係という問題設定をはずして，社会運 動を論じようとしている．つまり，反グローバル化運動の分析に主に用いら れている既存の枠組では，国家と市民社会は対抗しあうものとされるか，中 心的な分析視座とされていない。これに対し，グローバル化に対応する運動 との関連では，まだあまり注目されていない東アジア市民社会論は，国家と 市民社会を相互浸透しあう領域として位置づける。

現実の反グローバル化運動の中では，東アジア市民社会論の視角につなが るような要請もなされている。東アジア市民社会論は，この地域の特殊性と 内部的多様性を宿命として担いつつ，グローバル化に対応するトランスナシ ヨナルなネットワークを地域内に形成していくための理論的・実践的課題を 追求しつづけるであろう。

キーワード：グローバル化に対応する社会運動，国家，市民社会

\section{1 問 題 提 起}

1990 年代後半以降，グリーンピース，アムネスティ・インターナショナル，才 ックスファム，「国境なき医師団」など，国際NGOの世界で，自分たちの国際的 ネットワークを指して「グローバル市民社会」という言い方がされるようになっ てきた。またメキシコのサパティスタ民族解放軍の蜂起や，99年，シアトルの

*東洋大学社会学部教授 ohatah@soc.toyo.ac.jp

56 (2) 400 
WTO閣僚会議をきっかけに，新自由主義的なグローバル経済の拡大に異議を申し 立てる「反グローバル化運動」が注目を集めるようになってきた.

グローバル化が現代世界の趨勢を示すキャッチフレーズとなったことで，グロ ーバル市民社会には，グローバル化の問題点を克服する「オルタナティブなグロ 一バル化」としてのユートピア風のイメージが付与された。 反グローバル化運動 の戦闘的な激しさと「もうひとつの世界は可能だという力強いスローガンは, 袋小路に入っていたかにみえた世界の変革運動に新生面を開くようにもみえる。 しかし，そのような華々しさ以上に忘れてはならないのは，グローバル市民社会 と反グローバル化運動は，その登場以前から，非常にわかりにくく，あいまいだ った「市民社会」や「社会運動」という概念をさらに錯綜させたということだ。 その結果, 社会運動をめぐる国家と市民社会の関係の再考が必要になっている.

「市民社会」概念の形成と変遷をめぐる膨大で，更新され続けている検討に紙数 を費やすのは, 本稿の目的ではない. 包括的な定義の例というよりも, 本稿の論 議に結びつけやすい定義として，「国家とは区別される，社会におけるアソシェー ションの領域」（Shaw 1999：269）という市民社会の定義を引いておこう。この ような伝統的定義において，市民社会は，国家に抵抗，対峙することもありうる という含意を含みつつ，国家と区別される領域として位置づけられている.

このような市民社会の定義にもとづきつつ, グローバル市民社会は，「市民社会 が，国民的形態から，グローバルな，リージョナルな，トランスナショナルな形 態へと拡張されたもの」（Shaw 1999：269）として定義される. 市民社会の不透 明な歴史のなかで，それがグローバルな意味を帯びはじめる起源を確定すること は困難だが, 一般的には, 第2次世界大戦後の国際機関の創設と, 国境を超えた イシューに対応するNGO, 社会運動のネットワークのトランスナショナルな発展 （Shaw 1999：271-72；Turner 1998：28-36）が近年におけるグローバル市民社会 論の隆盛をもたらしたといえる。John Keane（2003：1-2）は，1980年代におけ る，（1）ソ連・東欧の変革に起因する市民社会論ルネサンス，（2）衛星とコンピ ユータを媒介とした情報通信革命, (3) 平和連動, 環境連動に刺激された, われ われ自身が自己破壞的な世界システムの一員だという認識，（4）ソ連型社会主義 システムの新たなグローバル政治経済への編入，（5）新自由主義市場経済の世界 的拡張，（6）ポスト植民地新興国家の混迷，（7）内戦，民族紛争の多発というい くつかの流れを背景にして，90年代に入り，「グローバル市民社会」という合言 葉が，流布しだしたとする。

グローバル市民社会は対応する特定の「国民的形態」を有さないが，だかと いって，もはや国家と市民社会の関係を問題にしなくともよいということにはな らない. 国家と市民社会の関係は, 従来とは別の角度から検討されねばならない のだ.しかし，反グローバル化運動に関する今までの理論的研究が，この要請に じゅうぶんに応えているとは思えない. 後述するように，反グローバル化運動を 反システム運動として把握する Immanuel Wallerstein らは，古典的な国家／市民社 
会関係の前提を踏襲している，いっぼう，ネットワーク社会論に依拠して反グロ ーバル化運動の分析枠組を提示しょうとする Manuel Castellsらは，国家／市民社 会関係という問題設定を積極的に廃裹しょうとする.しかし，国家と市民社会と いう問題設定は，なお重要なのではないか．たた，その関係が，古典的な規定と は異なったものになってきていることもとらえる必要があるのではないか．この 点をはっきりさせるため, 狭義の「反グローバル化運動」より，もう少し広く 「グローバル化に対応する社会運動」全般をみることにする．東アジア（北東アジ アと東南アジア $)^{1)}$ における，グローバル化に対応する社会運動の位相の考察を通 じて，社会運動をめぐる国家／市民社会関係に関する別のモデルを提示する.

すなわち，本稿の目的は，グローバル化に対応する社会運動に関する3つの異 なった分析枠組に损ける国家／市民社会関係の位置づけを比較検討することを通 じて，筆者たちが生きている東アジアという地域の現実により根ざしつつ，グロ 一バル化の時代に即応した，市民社会論の組み換えへの道を模索することにある. 対比する分析枠組とそれらにおける国家／市民社会関係の位置づけは，次のとお りである。

（1）反システム運動論 $\rightarrow$ 対抗する国家と市民社会（第2節）

(2) ネットワーク社会論 $\rightarrow$ 国家／市民社会問題の脱争点化（第3節）

（3）東アジア市民社会論 $\rightarrow$ 相互浸透する国家と市民社会（第4節）

第5節の考察においては，(1)〜 (3) を対比したうえで, 現在までのところ, 反 グローバル化運動の分析に用いられているのは，主に（1）と（2）だが，現実の 反グローバル化運動の中には，（3）のような国家／市民社会関係のとらえなおし につながるような要請もみられることを示す，そのうえで，東アジア市民社会論 という枠組を主張し，それをグローバル化に対応する社会運動と結びつけようと する本稿の試みに対し，当然，提起されるであろういくつかの批判にあらかじめ 答えておきたい.

無用の混乱を避けるためにも，市民社会やグローバル市民社会という用語のい くつかの異なった用いられ方に留意する必要がある. 遠藤貢 (2000a) は, 市民社 会概念が有する, (1) 分析の道具, (2) 規範・モデル (イデオロギー), (3) 現実・実 体という3つの側面（「顔」）を区別している，同様にKeane（2003：3-4）は，グ ローバル市民社会という用語法を，a）分析一叙述的 (analytic-descriptive)，b) 戦略的, 政治的な計算 (strategic political calculation), c) 規範的な理念 (normative ideal）という3つの方向に大別している. Keane（2003：3）が指摘し ているように，グローバル化に対応する社会運動の世界における「グローバル市 民社会」という用語法は，だいたいに扔いて，分析一叙述的というよりも，戦略 的，政治的な計算に属する．本稿でいう「市民社会」にはそのような運動言説と しての側面が切り離しがたく刻印されることは避けられないのである. 


\section{2 対抗する国家と市民社会一反システム運動論}

\section{1 反システム運動としての反グローバル化運動}

Wallerstein と同僚たちは，1980年代初頭から，資本主義世界システムの構造的 過程によって生みだされ，システムを変革しようとする「反システム運動」の研

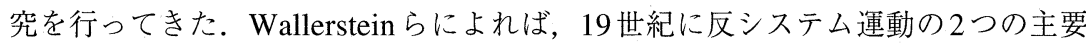
な類型が生まれた。ブルジョワジーに対する階級闘争としての「社会運動」(社会 主義運動）と，国民国家の創出をめざして闘う人びとの運動としての「民族運動」 (民族解放運動) である。これらの運動はいずれも，国家権力を獲得した後に世界 革命へという二段階革命論をとっていたとされるが，第一段階で国家権力を獲得 した後に体制化し，変革への潜在力を失っていく．68年に世界各地で生じた学生， 市民，労働者の蜂起（Wallersteinらは「世界革命」と呼ぶ）は，世界システムと ともに，体制化した旧来の反システム運動へも向けられた，新たな反システム運 動の波だった（Arrighi et al. $1989=1992 ）$.

1968 年以後の反システム運動として，Wallerstein $(2003=2004: 370-75)$ は, （1）毛沢東主義集団，（2）新しい社会運動，（3）人権組織，そして（4）反グロー バル化運動をあげている。このうち（2）（3）は否定的に評価されている．（2）に ついては，「急進派」と「現実派」への内部分裂の後，「急進派」が敗退していき， 「現実派」は昔ながらの社会民主党とさほど変わらないものになってしまったとい う指摘がなされる。（3）の典型とみなされる国際 $\mathrm{NGO}$ は，国家に対する反対者と いうよりも，国家の補助機関のようなものになり，反システム的とはいえなくな ってしまったと評価されている。これに対し，反システム運動のもっとも新しい 形態とされる反グローバル化運動にたいしては，かなり肯定的な評価がなされて いる．Wallersteinらは，反グローバル化運動のどのような点を，また，なぜ高く 評価しているのだろうか.

\section{2 批判的考察——国家/市民社会問題の棚上げと反グローバル化運動 の高評価}

市民社会と国家の関係についてのWallersteinらの言及には，1980年代末から最 近にかけて，微妙な変化がみられる。

1980 年代末の言及では，市民社会を統制する国家の能力が減少しつつあるとさ れている．国家権力対市民的権利および自由という問題が，国家／市民社会関係の中 心問題であるとみなされ，このような国家対 市民社会の図式が，世界規模の人権 運動へと拡大，保持されているとみなされる（Arrighi et al. 1989=1992：124-25）.

ところが，21世紀に入って以降の言及では，市民社会という概念は，人権組織 が用いる戦略と結びつけられている。1980年代末の文脈では「国家による市民社 会の統制（それに対する市民社会の抵抗？）」が問題とされていたのに，21世紀 の文脈では，逆に「市民社会による国家の制御」が問題にされている。しかし， 
前述の通り，Wallersteinは，人権組織が人権問題に国家の政策を向けさせるのに 成功した代償として，人権組織は国家に対する反対者ではなく，国家の補完物と なっていったことを指摘する。

もし，市民社会が国家への影響を増すことで，逆に国家に従属していくのだと したら，このような国際NGOによって担われるグローバル市民社会を反システム 運動の潮流にどのように位置づけるかは悩ましい問題になるかのように思われる。 ところが，前述したように，Wallersteinは，グローバル市民社会と反グローバル 化運動をほぼ同一視しつつ, 肯定的に評価している. Wallerstein $(2003=2004$ : 373-75）が，反グローバル化運動の例として言及しているのは，シアトルでの反 WTO 運動から世界社会フォーラムへと至る一連の流れであるが，反グローバル化 運動は，旧左翼から新しい社会運動までを含む従来のすべての運動，さらに「北」 に基盤をおく運動と「南」に基盤をおく運動を，新自由主義的なグローバル化に 反対するという単一の目標にしたがいつつ，全体を統括する上部組織なしに，ひ とつの枠組へとまとめあげることに, ある程度, 成功した点が高く評価されてい る. Wallerstein自身，2004年のインド，ムンバイでの第 4 回世界社会フォーラム にも「帝国主義的グローバル化」セクションの基調講演者の 1 人として参加して いる (Vanik 2004: 62). このムンバイ・フォーラムについても, Wallersteinは組 織運営上のいくつかの問題点を指摘しつつも, 概して好意的である (Wallerstein $2004=2004:$ 149-56).

このような世界社会フォーラムにたいするWallersteinの高い評価はどこから出 てくるのだろうか。それは，かれが現在を世界システムの移行期でありながら， 左翼の世界的な衰退期として位置づけ, この時期の重要な課題として「持続的. 開放的な討論」と「暫定的な中期的目標」を強調していること（Wallerstein $2003=2004 ： 377-78 ）$ と結びつけて理解すべきだろう．つまり，グローバル市民 社会というフレーミングは，困難な退却戦を戦う左翼によって「戦略的・政治的 な計算」にもとづいて利用されているのである。しかし，その中で，原点にあっ た，国家と市民社会の関係の問題は解決されていない。いや，フレームに余計な 波風を立てぬよう，意図的に棚上げにされているといっても過言ではあるまい.

しかし, 反システム運動論の本来的な枠組からすれば, 国家と市民社会とは, はっきりと区別されるだけでなく対抗しあうものと位置づけられること，その前 提にてらして，国家の「補完物」と化すような運動は批判されるべきものである ことを確認しておこう。

\section{3 国家/市民社会問題の脱争点化——ネットワーク社会論}

\section{1 社会運動論としてのネットワーク社会論}

Castells は，情報化時代のグローバルな社会構造の特徵を「ネットワーク社会」 として把握することをめざした 3 部作の第 2 巻を, 反グローバル化運動を含む現代 
の社会運動の分析に充てている. 3 部作冒頭に『論語』の「子孔は一以てこれを貫 く」を引いたCastellsが，ネットワーク社会の社会運動を分析する基本的視点は， 「抽象化され，普遍化した道具主義と，歴史に根ざした，個別のアイデンティティ のあいだの根本的分裂」，すなわち「ネットと自己という二極的な対立」をめぐる 社会の構造化である (Castells 2000a: 3).

樋口直人と稲葉奈々子は, Castellsのネットワーク社会論を, Alain Touraine と その後継者たちによる新しい社会運動論を乗り越え, グローバル化に対応する現 代の運動の分析に有用な視点を提供するものとして肯定的に評価し，運動分析の 用具としての整理を試みている.

前節で夕たWallerstein らが，基本的に国家と市民社会を対抗しあうものととら えつつも, 戦略的, 政治的な計算にもとづいて，そのことをあまり強調しないよ うにしているのに対し, Castellsやそれに依拠する樋口らは，自らの枠組にてらし て, 国家と市民社会という問題構成を意図的に廃棄しようとする。かれらはなぜ そうするのだろうか.

\section{2 「市民社会」「国家」の後退と「共同体」の強調}

Castells（2000a：421）によれば，ネットワーク社会の本質を象徴する場は， 「フローを通じて作動し, 時間を共有する社会的実践の物的組織」としての「フロ 一の空間」である。その典型的なあらわれは, 電子ネットワークを媒介としたバ 一チャルな空間と考えても大きな誤りはなかろう。ネットワーク社会に拈いてフ ローの空間を支配するエリートは，コスモポリタンになる。これに対し，民衆は ネットワークから排除されたローカルな存在となる. 民衆は, グローバルで用具 的なものに準拠することなく, 特定の場所, 歴史, 文化に根ざしてアイデンティ ティと意味を構築していくことになるのだ。このような特定の場所から，反グロ 一バル化運動, 原理主義運動, 環境運動, セクシャリティをめぐる運動などが生 成していくとされる.

ここで問題になるのは，社会運動の生成における市民社会の位置づけである.

Castells（1997：11）は，ネットワーク社会に扔いて，市民社会はグローバル・ネ ットワークの力と結びつきをもたないゆえに, 収縮・解体の方向へ向かい, 抵抗

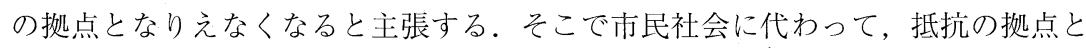
なるのは，アイデンティティを共有する「共同体集団」(コミューン）である．共 同体集団は，グローバル化に抗する「抵抗アイデンティティ」(resistance identity) （例：宗教的原理主義）を育むだけではない. 社会構造全体を変えようとする新た な行為者のアイデンティティである「構想アイデンティティ」 (project identity) （例：環境運動，女性運動）さえも, 市民社会を媒介としてではなく, 共同体的な 抵抗の延長に見出されるとされる.

同様に，Castells（1997：304-05）は，国民国家の位置づけについての再考も促 す。ネットワーク社会に扔いても, 国民国家は存在しつづけ, 一定の意思決定能 
力を保持しつづけるだろう。しかし，それはもはや「より広範な力のネットワー クの結節点」であるにすぎず，「それ自体としては無力な存在」と化しており，今 後ますますそうなっていくだろうと, かれは展望する。つまり，ネットワーク社 会論では，国家と市民社会というような従来的な問題構成はたいして重要ではな くなるのである．社会運動について考察する場合も例外ではない.

樋口直人と稲葉奈々子（2004）は，こうしたCastellsの論議を，市民社会を中核 概念とした（前期）Touraine学派的な新しい社会運動論に対する批判と乗り越え の試みとして評価する．新しい社会運動論は，「市民社会の防衛・再創造」を中心 テーマとしてきた。しかし，1980年代以降，Touaine学派は社会運動のなかに新 たな歴史形成主体を見出せなくなっていく，樋口ら（2004）は, 「市民社会の防衛」 をモチーフとする新しい社会運動論は，「国民国家を自明の分析単位とする一国主 義」プラス「発展段階論」という固有の限界を持っていたとし，「フロー空間」に たいする「共同体的抵抗」を重視するネットワーク社会論に，その限界突破の可 能性を託すのである。

たしかに樋口ら（2004）は，グローバル化に対応する社会運動についての，ネ ットワーク社会論とは別の分析枠組として, 政治的機会構造論にもとづくグロー バル市民社会論にも言及している。しかし，グローバル市民社会にふれる際にも， 「北」の国際NGOが好むようなかたちに，「南」の共同体的集団が変形される危険 性をかれらは指摘し，むしろ「グローバル市民社会の側から個々の共同体に近づ き，それを変形も排除もせずに対話可能なものと」（樋口・稲葉 2004: 222）しな ければならないと主張するなど,「共同体」に比して「市民社会」の位置づけは二 次的だといえる。稲葉（2004）は，さらにはっきりと，市民社会を近代の「大き な物語」として位置づけ，反グローバル化運動を「大きな物語」との関係で2つ の分極化したグループに区分する．グローバル市民社会は，「市民社会」「反資本 主義」「もうひとつの世界は可能だ」といった，「大きな物語」を作らうとする者 たちのグループであり，その典型が世界社会フォーラムである。これに対し, 共 同体集団は，「大きな物語」から排除された者たちであり，その典型は，サパティ ス夕が代表するような, 貧困層, 移民労働者, 失業者, ホームレスなどたとされ る。

まとめていえば, Castellsや樋口らのネットワーク社会論は,「グローバル化が もたらす分極化は市民社会や国家という中間的な媒介項を一気に迂回して, 『共同 体とフロー空間』の直接的な対峙を帰結する」（樋口・稲葉 2004：192）という言 明に端的にみられるように，「市民社会」「国家」が従来有していた中心的な位置 づけを否定し，「共同体」を強調することで, 国家/市民社会問題の脱争点化をは かるものといえる.

\section{3 批判的考察—「共同体」と「市民社会」の連続性}

壮大でありながら，「一以て」貫かれているネットワーク社会論は，非常に魅力 
的な分析枠組である。しかし，グローバル化に対応する運動についてみるうえで, 国家と市民社会の関係に注目しなくてもよいかについては，疑問の余地がある.

第 1 に，グローバル化に対応する運動に扔ける「共同体」的性格と「市民社会」 的性格とは，完全に分極化したものだろうか．稲葉によって，「フロー空間から排 除された共同体」の側に位置づけられたサパティス夕は，実際はさまざまなメデ イアを介して, 市民社会に積極的な働きかけを行っている。サパティスタの蜂起 によって，メキシコの民主化は政治的領域から市民社会と文化の領域にまで進み， 市民社会のなかに新たな政治参加の空間が開かれたとする評価さえある（Gilbreth and Otero 2001)。 また世界社会フォーラムは，シアトルの抗議の後，唐突に出現 した公共空間ではなく, 1990年代末から，サパティス夕の主導と努力のもとに行 われてきた反グローバル化運動グループのフォーラムに起源を有するものである (Seone and Taddei 2004)。つまり，稲葉によると共同体集団に近いとされる主体 が，グローバル市民社会を作り出しているのだ.

第2に，たしかCastellsは，共同体集団（コミューン）によるネットワーク社会 への対抗を重視している。しかし，Castellsが言う「コミューン」は，融通性と開 放性を備えた概念であり，「共同体」という文字からわれわれが連想する自己完結 性と閉鎖性とはかなり様相が異なる，ネットワーク社会論に関する別稿で Castells (2000b：22-23）は，ネットワーク社会に変動をもたらしうる要因を2つに分けて いる. 1つは, 自己充足的な意味を中心に扔く「文化的コミューン」であり，宗教， ナショナリティ, 地域, エスニシティなどにもとづくコミューンはこの類型に属 する。もう1つ，Castellsがあげているのは，「オルタナティブなネットワーク」 であり, 環境運動, 女性運動は, こちらの類型に属するとされるのだ。グローバ ル化に対応する自生的な運動の主体を，排除され孤立した「共同体」としてとら えるのではなく, それ自体, 開かれた「オルタナティブなネットワーク」として とらえれば，それらのネットワークと市民社会とは，ある程度，連続的だと考え られる，そのように考えていくと，ネットワーク社会に掠いて市民社会が必ず解 体・収縮するとは，いちがいにはいえないのではないか.

残された問題は，市民社会的要素と国家との関係である．グローバル化に対応 する社会運動について考えるためには，ネットワーク社会論が主張するように， 国家を単なるグローバルなネットワークの「結節点」としてとらえるだけで，は たしてじゅうぶんなのだろうか.

\section{4 相互浸透する国家と市民社会一一東アジア市民社会論}

筆者は, 東アジア社会研究者として, 反システム運動論やネットワーク社会論 から多くを学び，刺激を受けつつも，何かしらの違和感を禁じざるをえない. 東 アジアは, 世界の多くの地域と同様に，グローバル化の大きな影響にさらされて いる．グローバル化に対応する社会運動も生じている．運動の文脈のなかで市民 
社会も論じられている。にもかかわらず，グローバル化に対応する東アジアの社 会運動にみられる国家／市民社会関係は，既述した反システム運動論やネットワ 一ク社会論の主張とは，かなり異なった性格を帯びている2).たた，この点に立 ち入る前に，1990年代にはいってグローバル化の徴候が顕著になる以前から，東 アジアの市民社会論を規定している文脈，すなわち民主化についてふれておかね ばならない。

\section{1 東アジアにおける民主化と市民社会形成}

東アジアに打りる市民社会への関心は，東欧の変革に端を発した市民社会論り バイバルに刺激され，アフリカ，ラテンアメリカなど他の非西欧地域の場合と同 様に，自らの地域の漸進的民主化過程と結びついて生じた。市民社会への関心は， 民主主義への移行と，民主主義の定着ないし「強固化」（consolidation）という2 つの段階で，それぞれ異なった含意を有する。

民主主義への移行の過程，すなわち権威主義的な政権が打倒され，自由選挙な ど制度的民主主義が成立する段階に関しては，変革の担い手が，経済成長を通じ て生じた中間層（ニュー・リッチ）であり，かれらこそが市民社会の中核集団だ ったのではという点が注目される。

民主主義の定着ないし「強固化」の段階においては, 政府への市民参加が強調 される，市民社会の課題として，市民が継続的に組織された形態で政治に参加し， 政治の監視，監督，方向づけをなすことが強調され，そのための重要な集合行為 形態として, 環境運動, 労働運動, 女性運動, 貧民運動, 平和運動などを含む, 広い意味での市民運動の役割が重視される。このような民主化と市民社会の動学 はグローバル化の影響が強まるなかで，異なった様相を示してくる。

\section{2 グローバル化が民主化，市民社会形成に与える影響3)}

グローバル化は，東アジアの民主化，市民社会形成にどのような影響を与えた だろうか。

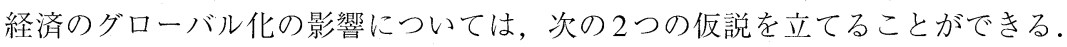
（1）経済のグローバル化は，権威主義的政治体制からの解放をもたらし，民主化 を促進する。（2）経済のグローバル化は，それに即応してとられる新自由主義的

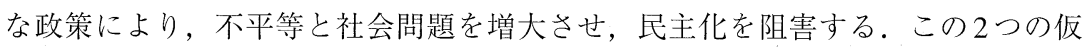
説の対立は，東アジア地域研究において，今なお争点となっており，いずれがよ り妥当であるかの決着はついていない，今のところ言えるのは，経済のグローバ ル化が民主化に与える影響は, 単純に促進的とも阻害的とも断定できない複雑な ものであり，媒介変数としての国家／政府のあり方が重要だということである.

むしろ注目すべきであるのは, 社会のグローバル化, すなわち, グローバル化 によって，市民社会に新たな政治的機会構造が作りだされるという点である。た とえば，グローバル化に対応する社会運動には，(1) エリート的なグローバル化 
に対抗して，オルタナティブなグローバル化を追求するか，(2）グローバル化へ の「全面的拒絶」を表明し，「ローカリズム」を強調するかという選択肢が生じる. あるいは, 別の例として, 移住労働者の増加のようなグローバル化のもたらす争 点への対応が，国境を超えた市民運動，労働運動組織間の連絡と協力をもたらし ていくこともある.オルタナティブなグローバル化という選択肢の追求や，国境 を超えた組織間の協力が，東アジアの市民社会にトランスナショナルな性格を付 与していくと予想される.

ただ注意しなければならないのは，このようなトランスナショナルな市民社会 の形成が，ただちに民主化を促進するものとはいえないことである。ここで民主 化の「強固化」段階で明らかになる，東アジアにおける国家と市民社会の関係の 特質をみておこう。

\section{3 国家と市民社会の相互浸透，そして両方の民主化}

東アジア市民社会論は，地域の特性を反映し，西欧出自の古典的な市民社会論 とは異なった特性を示す．東アジア市民社会論の達成の全容を本稿で扱うことは できないが，国家と市民社会の関係設定という核心的な点に限って，東南アジア， 中国，韓国における論議の概略を紹介したい.

岩崎育夫（1998）は，イシドネシア，シンガポール，マレーシア，夕イ，バン グラデシュ，トルコの市民社会論的分析の総論において，市民社会と国家のあい だの原理的関係を「市民社会は組織的にも活動的にも国家から自律する」「国家は 市民社会からの働きかけに応答する義務と責任を負う」（岩崎 1998：18）という2 原則として設定した。しかし，東南アジア諸国の中でも，国家の性格は抢互いに 非常に違っている，タイとフィリピンは「弱い国家」で，市民社会に対する規制 はほとんどない。インドネシア，シンガポール，マレーシアは「強い国家」で， 市民社会に対する抑圧や制限が強い，古典的な国家／市民社会関係の理解からす ると，前者のような「弱い国家」のほうが，市民社会の活動の余地は多くなり， 活発な発達が期待できるように思われる。事実，夕イ，フィリピンの $\mathrm{NGO}$ や伝統 的な社会団体の活動は活発である。しかし，興味墚いのは，「弱い国家」では，国 家の市民社会の働きかけに対する応答能力も制約されるため，市民社会の発達が 阻害される側面があるという指摘もなされていることだ（岩崎 1998: 29-30）.

中国の市民社会論においては，斎藤哲郎（2004）によれば，1980年代後半，民 主化運動に従事した亡命知識人たちによる「(国家への) 抵抗モデル」が, 改革開 放後，批判されていき，「半市民社会論」「国家主導型市民社会論」「公共圈論」な どの，国家と市民社会の相互浸透・相互補完を強調したモデルが提示されていく. これらのモデルを，民主化運動の弾圧に起因する思想的反動として理解するのは 不適切だ。むしろ国家と市民社会の緊密な関係を強調することで，「『国家権力』 削減による『国家能力』拡大」（斎藤 2004：36）という改革戦略を読み取ること ができる．また欧米の市民社会論が「国家」「市民社会」「市場」という三層モデ 
ルにおいて，市民社会と市場を背反的に位置づける傾向があるのに対し，中国の 市民社会論は，市民社会と市場経済の一体的性格を強調する傾向があるという.

韓国市民社会論の潮流について，大畑裕嗣（1994）は「市民社会論に対するマ ルクス主義的対応」と「非マルクス主義的市民社会論」を，尹健次（2000：96） は「自由主義的市民社会論」と「左派的市民社会論」を区別した. 現時点からみ ると，どちらの区分もじゅうぶんなものとはいえないが，市民社会と国家の関係 という観点からすると, 韓国の場合, 親マルクス主義的立場をとる論者も非マル クス主義的立場をとる論者も，市民社会を「国家（権威主義的国家）に，消極的 に言えば取り込まれない，積極的に言えば抵抗・対峙するすべての領域」(大畑 2000：116）として，国家との（広義の）対抗関係において位置づけてきたといえ る．グローバル化と市民社会の関係でみると, アジア金融危機以降，非マルクス 主義市民社会論の流れのなかから，国民国家はグローバル経済の浸透によって， もはや共生の根拠としての地位を衰失しつつあり，代わりに市民社会を根拠とし た，新たな共同体を構想しなければならない（李時載 1998）というタイプの言説 が生み出されてくる.

しかし，韓国でも，特に金泳三政権期以降，「世界化」（グローバル化）言説を 介しての国家装置と市民運動組織の相互補完が進んでいく。たとえば，大畑 （2005）は，仁川国際空港建設問題に関して，「世界化」言説を中心としたマスタ ーフレームの磁場のなかで, 国策事業にたいする異議申し立てがいかに動員解除 され, 事業の基本的な方向づけとは矛盾しない, ポピュリズム的な「地域運動」 の動員がいかに促進されたかを解明しようとしている.

市民社会と国家の領域がはっきりと区別できるという古典的な市民社会論の前 提は, 東アジアの国家と社会にはたして妥当するのか. 東南アジアと中国の市民 社会論は, かなり明示的に, 国家と市民社会の相互浸透という異なった視点を打 ちだしている，韓国市民社会論では, 権威主義的国家にたいする市民社会の抵抗 という側面が重視されてきたものの，民主主義の「強固化」段階の現実を分析す るためには，国家と市民社会の相互浸透の契機をも考慮せざるをえまい。つまり， 1節で引いたShawの「国家とは区別される, 社会に拈けるアソシエーションの領 域」という市民社会の規定は，東アジアの市民社会には必ずしも妥当しない。こ こでいう市民社会は, 「国家が関与する領域も含めた，人びとが取り結ぶ社会関係 の総体」となる.

従来の市民社会論では，国家は抑圧に結びつけられるのに対し，市民社会は自 由な領域とされてきた（Diamond 1994）。国家と対応した（国内的）市民社会の みならず，対応物としての特定国家を有さないグローバル市民社会も，国家（政 府）から自立した自由な領域であり，「もうひとつの世界」のひながただみなさ れてきた。これにたいし，国家と市民社会の高度な結合を所与として考察をすす める東アジア市民社会論は，市民社会集団が，国家に抗して民主化闘争を行うと ともに，国家を介して民主化を追求する可能性をみようとする，さらに市民社会 
は自らを階級，ジェンダー，エスニシティなどの内部的不平等を含んだ間接支配 の領域とみなし，国家の民主化だけではなく，市民社会の民主化も追求するかも しれない（Uhlin 2003：153）。東アジア市民社会論は，国家と市民社会の相互浸 透を言うことによって，相互の「パートナーシップ」を無原則に礼賛，肯定する ような枠組ではない，それは，「国家＝抑圧的／悪」「市民社会（国内的であって も, トランスナショナルなものであっても）＝民主化志向的／善」という自明化 された定式化に疑問を投げかけ，国家と市民社会両方の民主化を視野に入れた， ねばりづよい変革を志向する枠組なのである.

\section{5 考察}

\section{$5.13 つ の$ 枠組と「市民社会を超えて」}

以上，グローバル化に対応する社会運動に関する3つの分析枠組における国 家／市民社会関係の位置づけを検討した。 反システム運動論は，国家と市民社会 が明確に区分され，対抗しあうこともあるという古典的な前提を踏襲しているが， おそらく反グローバル化運動の実態と関連した戦略的計算のため，その点をあま り強調しなくなっている。ネットワーク社会論は，ネットワーク社会における市 民社会と国家の位相を相対的に重視せず，国家／市民社会関係という問題設定を はずして，社会運動を論じようとしている．つまり，反グローバル化運動の分析 に主に用いられている既存の枠組では，国家と市民社会は対抗しあうものとされ るか，中心的な分析視座とされていない。これに対し，グローバル化に対応する 運動との関連では，まだあまり注目されていない東アジア市民社会論は，国家と 市民社会を相互浸透しあう領域として位置つける。

反システム運動論において，「市民社会（国際NGO）が国家の補完物となって いる」という言明が批判的含意を有するのは，上記の古典的前提に加え，「(国家 と市民社会の対抗関係において）国家は『悪いもの』であり，市民社会は『良い もの』である」という暗黙の前提が保持されているからである. しかし，当為的 判断を含むこれらの前提は，グローバル化する現代社会の状況の中で，はたして 常に妥当といえるだろうか.

ネットワーク社会論は，情報化社会の実証分析にもとづく理論的帰結として， 国家／市民社会問題を脱争点化する。しかし，市民社会の収縮・解体という予言 とは異なり，ネットワーク社会論がいう「共同体集団」を含みこみつつ，市民社 会がむしろ拡大している傾向はないか. また, グローバル化において, 国家は単 なる「結節点」以上の戦略的な役割を果たしているのではないか（Weiss 1997）. たとえトランスナショナルな性格を有する社会運動について考察する場合であろ うとも，国家／市民社会関係という問題設定は今な抢必要なのではなからうか.

とはいえ，国家と市民社会の相互浸透という東アジア市民社会論の視角は，本 稿冒頭に例示したようなグローバル市民社会や反グローバル化運動の主流の傾向 
とは相容れない，東アジアの特殊な文脈に起因する特質に言及したものにすぎな いのではという疑問も，当然のことながら提起されよう。この点に関連して，世 界社会フォーラムに扔ける「市民社会」概念の問題点に関する Emir Sader (2004) の次のような指摘に注意を促しておきたい.

Saderは，世界社会フォーラムの中核概念とされた「市民社会」が複雑で多義的 な意味を包含しつつも，包括的と排除的という2つの実質的な機能をはたしたと 指摘する，包括的というのは，世界銀行や大企業と「パートナーシップ」を組み つつ，それらの社会的補完機能を果たすNGOをフォーラムの参加者として受け入 れたことである．排除的というのは，政党と政府を「国家」のエージェントとみ なして，参加を認めなかったことである.

Saderは，このような「市民社会」概念の政治的利用がもたらした弊害を，むし ろ重視している．NGOの参加はともかく，政党や政府組織の参加を完全に排除し てしまって,「グローバルに考え，ローカルに行動しょう」とか「持続可能な発展」 といったNGO業界の呪文を唱えているだけで，新自由主義的グローバル化にたい するオルタナティヴが本当に出せるのか. 対抗的へゲモニーが確立できるのか. このような問題意識にてらして，Saderは「市民社会を超えて」世界社会フォーラ 厶を発展させる途を模索する。このような問題提起は重要ではあるが, 必要なの は市民社会概念の廃充ではなく，それを国家／市民社会の二分法から解き放つこ とであると筆者は考える.Saderの指摘に示されるような, 現実の反グローバル化 運動の方向性に関する批判的考察と，国家と市民社会の相互浸透という東アジア 市民社会論の視角のあいだに，何らかの収斂点が生まれる可能性はあるのではな いか.

\section{2 なぜ「東アジア」か?}

それにしても，なぜ「東アジア」なのか．本稿における「東アジアからの視角」 に対して提起されるだろう2つの疑問について簡潔に論じて結びに代えたい.

(1) 一般化の問題 南北問題を背景として生じる反グローバル化運動とグロ ーバル市民社会に関して,「北」と「南」のはざまで位置づけがはっきりしない東 アジアという地域に依拠して一般化を行扔うとしているのか？だとすればそれ は無理があるのではないか？——本稿が試みたのは，グローバル化に対応する 社会運動に関する一般化ではない。あくまでも，筆者が生きている東アジアの現 実にてらすと，グローバル化に対応する社会運動をめぐる国家と市民社会の位相 がどのようにみえるかの提示である．国家と市民社会の相互浸透を主張する東ア ジア市民社会論の射程は，早くから市民社会が成長したラテンアメリカ，宗教集 団の果たす役割が巨大な中東，市民社会の構成要素として共同体組織を無視でき ないサハラ以南アフリカなど, 他地域との比較研究に扔いて, 今後検証されてい くべきであろう ${ }^{4)}$. しかし，たとえば，アフリカ市民社会論の研究者からも，類 似の「国家と市民社会の相互浸透」の傾向が報告されている点（遠藤 2000b）は， 
今後の研究において看過されるべきではない.

（2）地域内の多様性の問題「東アジア」として一括された域内には，経済 発展，政治体制，人口規模，歴史・文化，民族構成などの，いずれの点において も，非常に多様な国家，政治体が含まれる。これらを，グローバル化との関連に おいて，一括してよいのか？一域内の多様性を認めたうえで，現在，この地 域においてエリート的な，あるいは草の根的な，さまざまなレベルで「東アジア 共同体」が提起され，地域内協力が模索されているという現実とどう向き合って いくべきか.かつての「アジア主義」に回帰してしまうという险路に陷らずに， グローバル化に対応するトランスナショナルなネットワークをこの地域内に形成 していくうえでの，理論的・実践的課題は何か. 問いに対して問いを返すかたち になってしまうが，東アジア市民社会論には，今，きわめて重く，かつ回避不能 なその問いが突きつけられているのである。

\section{[注]}

1）本稿では「東アジア」を，普通に言う「北東アジア」（モンゴル，中国，朝鮮半島，日本，台 湾など）と「東南アジア」を含む地域として考えたい。このような地域単位の設定は，1990 年代以降，この範囲の国家間に進み，現在，アセアン，中国からの「東アジアサミット」開催 要求というかたちで政治・外交的課題ともなっている,「地域化」(文化的, 地理的, 経济的, 地政学的近接性を強調した, 共通の統合的枠組の顕在化）の現実を踏まえてのことである. 谷 口誠（2004），菊池努（2005），天児慧（2005）を参照されたい.

2）東アジア社会への反システム運動論の適用は，中村則弘（2004）が行ったような，枠組の大 胆な読みかえをともなわざるをえない.

3）本項の論議は, Anders Uhlin（2002）に依るところが大きい.

4）この点をご教示くださった小倉充夫氏に謝意を表したい.

\section{[文献]}

天児慧，2005，「新国際秩序構想と東アジア共同体論——中国の視点と日本の役割」『国際問題』 538: $27-41$.

Arrighi, G., T. K. Hopkins and I. Wallerstein, 1989, Antisystemic Movements, London: Verso. (=1992, 太田仁樹訳『反システム運動』大村書店.)

Castells, M., 1997, The Power of Identity, Mass.: Blackwell.

, 2000a, The Rise of Network Society, 2nd ed., Mass.: Blackwell.

- 2000b, "Materials for an Explanatory Theory of the Network Society," British Journal of Sociology, 51(1): 5-24.

Diamond, L., 1994, “Toward Democratic Consolidation,” Journal of Democracy, 5(3): 4-17. 遠藤貢，2000a，「『市民社会』論—グローバルな適用の可能性と問題点」『国際問題』484: 2-16. —，2000b，「アフリカ『市民社会』論の展開」『国際政治』123: 13-29.

Gilbreth, C. and G. Otero, 2001,"Democratization in Mexico：The Zapatista Uprising and Civil Society," 
Latin American Perspecitives, 28 (4): 7-29.

樋口直人・稲葉奈々子, 2004,「グローバル化と社会運動」曾良中清司・長谷川公一・町村敬志・

樋口直人編『社会運動という公共空間——理論と方法のフロンティア』成文堂, 190-229.

稲葉奈々子, 2004,「グローバル化と社会運動」带刀治・北川隆吉編『社会運動研究入門——社会

運動研究の理論と技法』文化書房博文社, 198-224.

岩崎育夫，1998，「アジア市民社会論—一概念・実態・展望」岩崎育夫編『アジアと市民社会—

国家と社会の政治力学』アジア経済研究所, 3-38.

Keane, J., 2003, Global Civil Society?, Cambridge: Cambridge University Press.

菊池努，2005，「『地域』を模索するアジア一一東アジア共同体論の背景と展望」『国際問題』538:

42-55.

李時載, 1998, 「새로운 문명과 한국의 사회운동」『창작과 비평』100: 95-112.

中村則弘，2004，「反システム運動の崩壊からみた中国の産業化過程」『現代社会の構想と分析』2:

$75-86$.

大畑裕嗣，1994，「韓国における市民社会論の動向——『韓国の国家と市民社会』を読む」『思想』

844: $129-44$.

一，2000，「韓国の『民主化』と市民社会」古屋野正伍・北川隆吉・加納弘勝編『アジア社 会の構造変動と新中間層の形成』こうち書房, 108-29.

一，2005，「仁川国際空港と『世界化・環境・地域主義』のマスターフレーム」服部民夫・金 文朝編『韓国社会と日本社会の変容——市民・市民運動・環境』慶応義塾大学出版会, 77-110.

Sader, E., 2004, “Beyond Civil Society,” T. Mortes ed., A Movement of Movements: Is Another World Really Possible?, London: Verso, 248-61.

斎藤哲郎，2004，「現代中国市民社会論についての省察」『広島国際研究』10：25-38.

Seoane, J. and E. Taddei, 2002, "From Seattle to Porte Alegre: The Anti-Neoliberal Globalization," Current Sociology, 50(1): 99-122.

Shaw, M., 1999, “Civil Society,” L. R.Kurtz and J. E. Turpin eds., Encyclopedia of Violence, Peace and Conflict, San Diego: Academic Press, 269-78.

谷口誠, 2004, 『東アジア共同体』岩波書店.

Turner, S., 1998, "Global Civil Society, Anarchy and Governance: Assessing an Emerging Paradigm," Journal of Peace Research, 35(1): 25-42.

Uhlin, A., 2002, "Globalization, Democratization and Civil Society in Southeast Asia: Observation from Malaysia and Thailand," C. Kinvall and K. Jönsson eds., Globalization and Democratization in Asia: The Construction of Identity, London: Routledge, 149-66.

Vanik, A., 2004, "Rendezvous at Munbai," New Left Review, 26: 53-65.

Wallerstein, I, 2003, The Decline of American Power, New York：New Press.（=2004，山下範久訳 『脱商品化の時代—アメリカン・パワーの衰退と来るべき世界』藤原書店.)

- 2004, “The Future of Iraq: Reading the World' 04" (http://fbc. ighamton.edu /commentr. htm, Jannuary 29, 2005.）（=2004, 山下範久訳『イラクの未来一世界を読み解く’04』藤原 書店.) 
Weiss, L., 1997, "Globalization and the Myth of the Powerless State," New Left Review, 225: 3-27.

尹健次, 2000, 『現代韓国の思想』岩波書店.

\title{
The State and Civil Society in Social Movements Responding to Globalization: \\ An East Asian Perspective
}

\author{
OHATA, Hiroshi \\ Toyo University \\ ohatah@soc.toyo.ac.jp
}

This paper examines the views on the relationship between the state and civil society in three analytic frameworks on social movements responding to globalization: antisystemic movement theory, network society theory, and the East Asian civil society argument. Through this examination, it searches for a paradigmatic change in the civil society argument. The purpose of the change is to make the civil society argument deep-rooted in the East Asian soil on which we live, meeting the demands of our times of globalization.

Antisystemic movement theory follows orthodox assumptions that there is a clear distinction between the state and civil society, and that they can confront each other. Recently, these assumptions have been less emphasized because of the strategic calculation on the political use of anti-globalization movements. Network society theory analyses social movements without considering the relationship between the state and civil society, because it maintains that global networks will make the role of the state and civil society less important. In short, the state and civil society are presupposed to confront each other, or are not considered central to these main analytic frameworks on anti-globalization movements. On the other hand, the East Asian civil society argument, which has been less noticed in relation to social movements responding to globalization, regards the state and civil society as interconnected.

In actual anti-globalization movements, we can hear some voices to be resonant with the viewpoints of the East Asian civil society argument. The East Asian civil society argument will continue to address the theoretical and practical issues in building a transnational network responding to globalization in this region, bearing a 
geographical specificity and internal diversity as its own destiny.

Key words: social movements responding to globalization, state, civil society 